\title{
ÂNSIA DE TI
}

Lise Macpherson $^{1}$

Olhos, tuas mãos

Bocas, tua saliva

Suor, respiração, trovão

Os pensamentos giram, giram, giram

Pernas e pés, suaves

Seios, tua pele

O cheiro, teu sabor

No coração vertigem, vertigem, vertigem

Êxtase, paixão

Dentro de nós um vulcão

Saudade, necessidade

Do beijo, do gosto, do cheiro

No teu colo adormeço, adormeço...

${ }^{1}$ Heterônimo de Laura de Assis. Contato: rassis.laura@gmail.com

Página: www.veredassentimentais.com.br 